\title{
The nursing profession in South Africa - Are nurses adequately informed about the law and their legal responsibilities when administering health care?*
}

\author{
A Singh \\ LLM PhD \\ Lecturer, School of Law - Howard College Campus, University of KwaZulu-Natal
}

\section{Mathuray}

BCur, BNHons, LLM

Clinical Training Specialist, Life Entabeni Hospital, Life Healthcare Group

\section{OPSOMMING}

Die verpleegprofessie in Suid-Afrika - Is verpleegkundiges op hoogte van die reg en hul regsverantwoordelikhede in die gesondheidsorg?

Hierdie artikel focus daarop om te bepaal hoe ingelig verpleegsters is oor die reg en die norme en standaarde wat die verpleegprofessie in SuidAfrika reguleer. Die doel van die artikel is tweeledig: Eerstens, poog dit om vas te stel wat die internasionale norme en standaarde is wat in ander jurisdiksies toegepas word. Om hierdie rede is 'n wye spekrum van eerste wêreld, derede wêreld en outluikende ekonomiese jurisdiksies, waaronder die Verenigde State, Nieu-Seeland, Australië, Spanje, Thailand, Singapoer, Indië, Mexiko en Nigerië, geskies om vas te stel wat die internasionale standaarde is wat deur verpleegkundiges in die uitvoer van gesondheidsorg toegepas word en of dit vergelykbaar is met die poeisie in Suid-Afika. Wat voortspruit uit 'n oorsig van die internasionale, praktykregulasies, is dat daar 'n noemenswaardige ooreenkoms is met betrekking tot die uitdagings wat bestaan. Baie studies toon die gebrek aan kennis van die reg en verantwoordlikhede as 'n algemene rede vir die bron van wanpraktyk problem onder verpleegsters. Tweedens, ontleed die artikel ook die bestaande wetgewing in Suid-Afika krities om vas te stel of dit by die implementering daarvan voldoende is om vepleegkundiges die nodige kennis te gee on hulle in staat te stel on hul rol te verstaan wanneer gesondheidsorg aan pasiënte toegedien word. Alhoewel die bevindinge getoon het dat die meerderheid verpleegkundiges in Suid-Afrika kennis dra van die toepaslike wetgewing en hul regsverantwoordelikhede, is daar ook ' $n$ beduidende aantal verpleegkundiges wat geen begrip van die reg het nie en ook nie die omvang van hul diens en die verantwoordlikhede wat daarmee verband hou ten volle verstaan nie. Waar skuiwergate geïdentifiseer is, word strategieë voorgestel om die gehalte gesondheid deur verpleegkundiges aan pasiënte wat aan hulle sorg toevertrou is te verbeter.

* This paper was originally presented by M Mathuray as an LLM dissertation entitled - 'A Critical Evaluation of Nurse's Legal Knowledge and Its Impact in Preventing Nursing Malpractice in South Africa' (2017).

How to cite: Singh \& Mathuray 'The nursing profession in South Africa - Are nurses adequately informed 


\section{Introduction}

Nursing is a vital part of the healthcare system and nurses ${ }^{1}$ are described as the "heartbeat of healthcare." 2 They direct their energies towards the prevention, promotion, maintenance and restoration of the individual's health. Expansive knowledge is required for nurses to perform their duties and render holistic patient care competently, ethically and legally. What is apparent is that the nurse's role has changed significantly over the past two decades and includes wider specialisation, greater autonomy and more accountability. ${ }^{3}$ Nurses pledge to take responsibility for the care they provide and to answer for their own decisions. They are expected to perform their actions in accordance with the requirements of the nursing professional bodies and the law. When nurses are aware of their legal responsibilities and obligations, they would undoubtedly be better prepared to care for persons in their care to achieve better productivity and quality in their service delivery. ${ }^{4}$ This article focuses on ascertaining how well informed nurses are about the law and their legal obligations in the milieu in which they operate and administer services to persons who are entrusted to their care. While, the first part of the article seeks to establish what are the norms and standards that are employed by nurses in administering health care in other international jurisdictions, to assess whether this is comparable with the position in South Africa, the latter part analyses the existing regulations in South Africa. The thrust of the discussion here is to determine whether existing legislation and policies are adequate to provide nurses with the required knowledge to enable them to fully appreciate their role and responsibilities when administering health care to patients.

\section{Background}

In South Africa, there has been an alarming increase in medical malpractice litigation in both the public and private healthcare sector. According to Aon insurance company in South Africa, claims in excess of

1 The Nursing Act 33 of 2005 defines a 'nurse' as a person registered in a category under section 31(1) in order to practice nursing or midwifery. Professional nurse, practitioner, nurse auxillary, staff nurse means a person registered in terms of section 31 . Section 31 makes provision for a nurse to be registered to practice as a professional nurse, midwife, staff nurse, auxillary nurse and auxillary midwife. Section 43(1) stipulates the use of titles as Registered Professional Nurse, Registered Midwife, Registered Staff Nurse and Registered Auxillary nurse. The reference to 'nurse' in this article will be used as a general term with reference to all of the categories described in the Nursing Act.

2 Botha 'Nurses are the Heartbeat of Healthcare' (2014) The Gremlin, available at http://www.thegremlin.co.za/2014/05/12/nurses-are-the-heart beat-of-healthcare/ (accessed 2016-02-27).

3 Scivener 'Accountability and Responsibility: Principle of Nursing practice B' (2011) Art and Science, Nursing Standard 25(29) 35-36.

4 Mali \& Mali 'Effect of Self-Instructional Module on Knowledge Regarding Medico Legal Responsibilities among Nurses' (2014) 3 (3) IJSR, 617 -618. 
five million rand have increased by $900 \%$ and on average, one in every five claims are in excess of one million rand, representing a $550 \%$ increase in the last decade. ${ }^{5}$ In a public address in March 2015, the Health Minister of South Africa, Mr Aaron Motsoaledi stated that medical litigation has reached crisis levels, calling it an 'explosion' of medical malpractice litigation. ${ }^{6}$

It is therefore imperative for nurses to know and understand the legal environment in which they practice. ${ }^{7}$ The current healthcare challenges of resource deficiencies, high acuity patients, increased complexity of information, advanced technology and more challenging disease profiles means that the nurse must know and understand the legal rights and implications essential for them to practice. These include the legal environment, regulation of nursing practice, standards of care, prevention of malpractice, professional liability, insurance and issues related to nurses. ${ }^{8}$ Nurses must be able to understand the law that governs their practice in order to obviate risks and lawsuits. This knowledge of legal responsibilities for the nurse is integral with the expanding demands in their clinical roles. 9 The question that arises therefore is: do nurses have the necessary legal knowledge in order for them to understand their practice and their responsibilities?

South Africa is faced with what has been referred to as a 'nursing crisis.' Much of this can be attested to critical human resource constraint, disinterest in the profession, lack of a caring ethos, and an apparent imbalance between the needs of the carer and the needs of the community. ${ }^{10}$ The nursing crisis alluded to above has been quadrupled by the enormous disease burden, the array of health sector reforms, gender stratification, and the existence of strong professional silos and hierarchies. Addressing these challenges is vital in order to strive towards Universal Health Coverage (UHC) in South Africa which aims to ensure that everyone is able to access the health care services they need, irrespective of whether they have the ability to pay for it. ${ }^{11}$ As a result of the rapid expansion of the scope of nursing care and knowledge, nursing staff face greater responsibilities and require increasingly more skills.

5 Aon 'Soaring medical malpractice claims demand statutory intervention' available at https://www.aon.co.za/index.php/en/news-articles/302-soaringmedical-malpractice-claims-demand-statutory-intervention (accessed 201703-15).

6 'SA's shocking medical malpractice crisis' (2015) Health 24 available at https://www.health24.com/News/Public-Health/SAs-shocking-medical-mal practice-crisis-20150309 (accessed 2016-02-27).

7 Haffiz \& Reshi 'Preparation of An Information Booklet and Its Impact on Staff Nurses Regarding Their Legal Responsibilities in Selected Hospitals of Kashmir Valley' (2016) 5(1) IJSR 1714-1717.

$8 \quad$ Ibid.

9 Ibid.

10 Rispel 'Transforming nursing policy, practice and management in South Africa' (2015) 8(10) Global Health Action 127-139.

11 Ibid. 
New specialities develop and nursing professionals rightly call for appropriate remuneration, authority and status. ${ }^{12}$

Historically, there was a distinct difference between the role and functions of a nurse and a physician. The nurse functioned within a delineated framework where it was adequate for the nurse to wait for the doctor to prescribe the order and medical treatment regime before they would follow that order. The nurse was expected to assist the physician and not question the physician's order, his practice or competency. The role of the nurse has changed dramatically over time. The locus of authority for the patient care decision making is now a shared function. The nurse's responsibility has been increased to encompass the actual examination, diagnosis and treatment without direct supervision of a physician. As a result of the higher acuity level of patients, the development of highly specialised technology and a heightened emphasis on independent nursing practice, the present position of nurses has increased accountability with a corresponding increase in legal liability. The increased utilization of less-skilled personnel, in an attempt to meet the health-needs impact on quality patient care. These personnel are used outside their scope of practice, creating a high-risk environment for patients and healthcare workers. ${ }^{13}$ Therefore, there must be comprehensive education on legal aspects that guides the nursing practice and a thorough understanding of the law for nurses to be adequately protected and to be held accountable for their legal obligations. ${ }^{14}$ This begs the question of what exactly does the accountability of a nurse entail.

\section{The nurse's accountability and responsibility}

Safety and quality of patient care is determined by the environment in which care is provided. Nurses are expected to apply their knowledge, skill and experience to care for the needs of the patient. When care falls short of standards, due to resource allocation or the lack of an understanding of relevant policies and legislation, the nurse bears this responsibility. The nurse is responsible for maintaining and updating nursing skills and competencies, having proper documentation, and fully understanding one's role as a healthcare practitioner. A nurse is bound to a standard of conduct that is expected of a reasonably prudent nurse. ${ }^{15}$ While all nurses are required to be familiar with the relevant legislation and regulations governing their profession, the practical reality is that this is not the case. As consumers are becoming increasingly aware of their legal rights in health care, all nurses are

12 See Verschoor, Fick, Jansen \& Viljoen Nursing and the Law (2007) 3.

13 Dorse Legal and Ethical aspects of nursing practice in selected private hospitals in the Western Cape Metropolitan Area (MCur dissertation 2008 University of Stellenbosch) 86.

14 Cavico \& Cavico 'The Nursing Profession in the 1990's: Negligence and Malpractice Liability’ (1995) 43(4) Cleveland State Law Review 557-626.

15 Lacer 'Nurses and Lawsuits: A Medico legal Perspective' (2010). 
therefore expected to have a thorough knowledge of their legal responsibility. The researcher, therefore, maintains that it is absolutely essential that nurses know and understand their legal rights and responsibilities in the domain of their practice.

\section{An overview of the nursing profession internationally}

\section{Nursing regulations and the practice in other countries}

Although nurses share a common profession, internationally their educational preparation, regulation, and practice patterns are diverse and vary in complexity and scope. There are differences in credentialing requirements that include professional licensure, use of titles, and accreditation of educational programs. ${ }^{16}$

Acquiring global standards for the education of nurses has been promoted by the International Council of Nurses (ICN) for over a century. Achieving that goal remains challenging and is complicated by the discrepancies in nursing education throughout the world. The minimum criteria for entrance is university level education in many countries, but this criteria of university education for nursing remains challenging, with disparities in the programs currently offered in different parts of the world. Furthermore, the issue is compounded because there are countries that still consider initial nursing education at the secondary school level to be adequate. The curricular in nursing education programs are diverse and varied across the world. Nurses from the Philippines complete a baccalaureate degree. Denmark, Ireland, New Zealand, and Spain also have single programs for qualifying as a nurse. In the United States, there are three educational pathways to become a registered nurse: a 2-year associate degree, a 3-year diploma program, or a baccalaureate degree. Also in the United States, the model of nursemidwife is common, for other countries midwifery is considered a profession separate from nursing. In a nutshell, universal nursing education standards have not been achieved. Global standards continue to be a goal of the future and these will be guidelines that serve as benchmarks for the profession. ${ }^{17}$

Another significant difference in nursing education globally is the regulation of the profession. Statutory nursing regulation is prevalent in most countries with the aim of ensuring a safe and competent nursing workforce. However, in contrast, there are still countries with no nursing regulation, rules, or other regulatory mechanisms that emanate from the government. In some countries, there is provision for nursing regulation,

16 Nicholas, Davis \& Richardson 'The Future of Nursing: Leading Change, Advancing health: International Models of Nursing' (2011) Institute of Medicine 565-642.

17 Ibid. 
either in statute or in other systems of rules, however, for various reasons no mechanisms exist that establish a legal framework for nursing as an autonomous regulated profession and licensure is not a mandatory requirement. Some countries require nurses to pass an examination after completion of their nursing education before they can practice. Nurses in the Philippines, Australia, Thailand, Singapore, the Cameroons, Korea, and Poland take a licensing exam that provides national licensure and registration as a first level (registered) nurse. Other countries, such as Mexico, do not require a post-graduation examination. The nursing schools administer an exit or qualifying examination and upon passage, the student is granted a diploma. The diploma allows the graduate to practice as a nurse. Titles are used to inform the public of the scope of practice and the professional identity of a healthcare worker and differ by country. The nurse's role and responsibilities may also differ by country, although the titles may be the same. ${ }^{18}$

It may be argued that although the common objective of the profession is universal with the main aim of restoring and promoting health, alleviating illness and protection of the patient, there remains an inconsistency on how the profession is regulated across the world and it is this discrepancy that may potentially be the root cause of varying standards in the delivery of care. Some of the factors contributing to nursing negligence have been documented as an inappropriate delegation whereby nursing tasks are delegated to unlicensed assistive personnel. Early discharge, nurse shortage, advances in technology, increased autonomy and responsibility of the hospital, better-informed customers and expanded legal definitions of liability are comparable contributors as in the South African context. ${ }^{19}$

Studies conducted on international and national grounds have revealed that nursing staff knew little of the law pertinent to their work and workplace. A study in Barbados has revealed that the majority of respondents did not know the contents of the law specific to their codes of practice and the workplace. ${ }^{20}$ It was identified in this study, that nursing professionals were unaware of how to deal with ethical and legal issues that they faced as they had insufficient knowledge of the law pertaining to them. A strong recommendation was to devise a means to sensitise them through practical education in ethics and ethical and legal approaches. $^{21}$

Sharmil examined the awareness of nurse's knowledge on legal aspects of health care in Madras, India. Qualitative data was collected and the findings provided information about the present knowledge of nurses on legal aspects of health care where $43.3 \%$ of the nurses in the

18 Ibid.

19 Croke 'Nurses, Negligence and Malpractice' (2003) 103(9) AJN 54-64.

20 Hariharan, Jonnalagadda, Walrond \& Moseley 'Knowledge, attitudes and practice of healthcare ethics and law among doctors and nurses in Barbados' (2006) 7(7) MNC Medical Ethics 1-9. 
study had inadequate knowledge and $56.7 \%$ had moderate knowledge. In order to provide quality care and legal protection, the interventions suggested was the updating of legal knowledge through continued education. ${ }^{22}$

To determine the nurse's knowledge in ethics, Osingada et al have concluded from a quantitative study conducted in Uganda that nurses exhibited very little knowledge in ethics and recommended structured continuing programs in developing their knowledge on ethics in practice. ${ }^{23}$ Nurse's knowledge was also examined by Oyetunde and Ofi in hospitals in Nigeria where $41.6 \%$ demonstrated a knowledge deficit about the laws of the land and its application and $77.6 \%$ demonstrated a deficit in knowledge regarding laws governing their practice. ${ }^{24}$

In a study conducted by Mali and Mali in India, the nurse's knowledge was assessed regarding medico-legal aspects. The results revealed that nurses had inadequate knowledge regarding medico-legal responsibilities. ${ }^{25}$ To corroborate this finding, Indian nurses participated in a separate but similar study whereby knowledge of legal awareness was assessed and found to be hugely lacking. ${ }^{26}$ Similar to the above findings, Kaur et al recommend the need for an information booklet that will help independent learning in nurses of knowledge regarding legal responsibilities. $^{27}$ This recommendation arises from the findings of a study conducted to assess the knowledge regarding legal responsibilities in nursing. Although the results revealed a moderate to good knowledge base of legal responsibilities, the authors confirm the deficit of aspects such as the law and legal terms and its application thereof. ${ }^{28}$

What is evident from an overview of international regulations pertaining to the nursing practice is that similar challenges exist throughout the world. The main priority and common thread, however, remains the safety of the patient and the enhancement of regulations governing practice to protect this vital human right. Irrespective of where one lives in the world, one's well-being depends on how health issues are managed. It is apparent that South Africa is not unique in the challenges experienced in the nursing profession. This is highlighted in the plethora

22 Sharmil 'Awareness of Community Health Nurses on legal aspects of Health Care' (2011) IJPH 199-218.

23 Osingada, Nalwadda, Ngabirano, Wakida, Sewankambo \& Nakanjako 'Nurse's knowledge in ethics and their perceptions regarding continuing ethics education' (2011) 8 BMC Research Notes 319.

24 Oyetunde \& Ofi 'Nurse's knowledge of legal aspects of nursing practice in Ibadan, Nigeria' (2012) 3(9) JNEP 80.

25 Mali \& Mali 'Effect of Self-Instructional Module on Knowledge Regarding Medico Legal Responsibilities among Nurses' (2014) 3(3) IJSR 61 7-624.

26 Kumar, Gokhale, Jain \& Mathur 'Legal Awareness and Responsibilities of Nursing Staff in Administration of Patient Care in a Trust Hospital' (2013) 7(12) JCDR 1-11.

27 Kaur, Sodhi \& Sharma 'A Study to Assess the Knowledge Regarding Legal Responsibilities in Nursing’ (2014) 2(1) IJHS 50-53.

28 Ibid. 
of cases dealing with malpractice issues of nurses that have been brought before our courts.

\section{An examination of South African case-law illustrating the challenges experienced by nurses}

Registered nurses execute tasks previously performed by other healthcare practitioners while ancillary staff performs roles usually associated with registered nursing staff. The challenge lies where the boundaries between healthcare staff continue to shift. In the past ten years there has been a revolution in the legal responsibilities of nurses as these reforms have led to attitude changes toward nurses by the legal, medical, and public realms. To avoid legal charges of negligence, nurses must keep abreast of the rapidly changing areas of technology, documentation, and patient care. Regardless of the healthcare setting, professional nurses are morally, ethically, and legally accountable for their nursing judgments and actions.

Nurses have a crucial role to play in providing patients with the necessary care. As indicated, empowering the nurse with the relevant legal knowledge from inception is vital in preventing incidents of nursing negligence. If the nurse does not have the necessary knowledge and understanding of the laws governing their practice, the rights and laws protecting the patient, and that which govern and regulate the healthcare institution, there is a likelihood that such an inadequacy may result in harmful consequences for the patient, the institution, and the nurse. The following cases highlight this predicament.

In Goliath $v$ MEC of Health in Province of Eastern Cape, ${ }^{29}$ the Supreme Court of Appeal upheld the appeal with costs for damages to the plaintiff where a swab was left in the plaintiff's abdomen post-surgery resulting in sepsis. In this case, both the doctor and the nurse were placed on trial, however, the failure to ensure the duty of care in this instance lies with the registered nurse who is in charge of her theatre and is responsible for a swab count. It is on her nod that the doctor will 'close' a patient once she confirms her swab count. A similar outcome had arisen in the Van Wyk $v$ Lewis case, where the surgeon had left a swab in the plaintiff's abdominal cavity following surgery. Although the court found that the defendant Lewis, was not negligent, the court held that it was the general practice that the attending registered nurse carried the responsibility to ensure that all swabs were accounted for. ${ }^{30}$

29 Goliath $v$ Member of the Executive Council for Health in the Province of the Eastern Cape [2015] JOL 32577 (SCA).

30 S v Van Wyk; S v Lewis [2002] JOL 9345 (C). 
Such negligence is again brought to the fore in Micheal $v$ Linksfield ${ }^{31}$ where a young man suffered a cardiac arrest resulting in cerebral anoxia which left him in a vegetative state whilst under general anaesthetic during a surgical procedure. Negligence was alleged during the resuscitation procedure as a result of the failure of the registered nurse to operate the resuscitation equipment correctly. As a nursing professional, competency in operating emergency equipment is vital and regarded as a basic requirement for safe practice. In this instance, it was unacceptable that the registered nurse practitioner was ignorant of the operating emergency equipment in her immediate work environment.

In Ntsele $v$ MEC for Health, Gauteng Provincial Department ${ }^{32}$ the medical staff had failed to exercise skill and diligence in the medical profession to the pregnant plaintiff and as a result, the plaintiff's child suffered hypoxia and perinatal asphyxia resulting in cerebral palsy. The court found in favour of the plaintiff as emergency care was not diagnosed and instituted. As nurses initiate their professional obligations, their legal responsibilities also begin.

Hoffman $v$ MEC of Eastern Cape ${ }^{33}$ also highlights the registered midwife's lack of reasonable care administered to a pregnant mother and her unborn child. From the evidence, it was obvious that the registered midwives failed to identify medical problems of distress with the baby and the mother timeously thus resulting in a delay in their actions and death of the child. The court found that the required level of skill and care was not evident by the attending midwives. A similar unfavourable outcome is seen in the matter of NP $v$ MEC for Health, Eastern Cape. ${ }^{34}$ As a result of poor nursing assessment, a child was born with a physical deformity that proved to be avoidable had a reasonable standard of care been adopted.

The application and implementation of laws and malpractice theories are used to determine direct or indirect liability for injuries when a nurse is placed on trial. What is clearly evident from an examination of caselaw, depending on the circumstances of the case, the hospital, the physician and the nurse may all be held liable. Nurse liability, however, is generally based on negligence principles. A nurse can only be held liable for injuries if they owed a duty of care to the patient, they breached this duty of care, and the breach resulted in measurable damage to the patient, ${ }^{35}$ as has been reflected in case-law.

31 Michael and Another $v$ Linksfield Park Clinic (Pty) Ltd and Another [2002] 1 All SA 384 (A).

32 Ntsele v MEC for Health, Gauteng Provincial Government [2013] 2 All SA 356 (GSJ).

33 Hoffman v MEC, Department of Health, Eastern Cape and Another [2011] JOL 27750 (ECP).

34 NP v MEC for Health, Eastern Cape [2014] (1196/2012) 28 (Unreported).

35 LaMance 'Nursing Liability Laws' (2014), available at http://www. legalmatch.com/law-library/article/nurse-liability-laws.html (accessed 201608-24). 


\section{The legislative framework that regulates the nursing profession in South Africa}

\section{Regulation of the profession}

Regulation of the nursing profession encompasses the welfare of the public through the improvement of education standards, practice standards and delivery of care to patients by ensuring that competency on all domains is inherent to nurses in order to provide quality care at all times. It ensures professional identification of nurses who meet the criteria for registration and provides for disciplinary hearings of those who wilfully or negligently harm the health of their patient. 36

The State as the chief custodian of its people has to ensure that those who are responsible for the welfare of people have the essential knowledge, skills, and ethical integrity necessary to ensure safe health care delivery standards. In the 19 th century, the registration of doctors and nurses was inaugurated. The regulatory control was provided through an Act of Parliament, the Nursing Act 33 of 2005 as amended (hereinafter referred to as the Nursing Act). The profession was granted the right to a regulatory authority which was to ensure that all its actions were in the public interest. Through the delegated function, Parliament was thus assured that it was and is currently carrying out its responsibilities to its citizens. This authority comprises accountability and responsibility. In South Africa, this regulatory body is the South African Nursing Council (hereinafter referred to as SANC). The nurses have the autonomy to determine the quality of care rendered and are accountable for their professional actions to SANC, or to the courts for alleged breach of the law and vice versa. However, SANC is, in turn, accountable to the State through representatives of the people. The minister designated in the Act is responsible to Parliament for this. ${ }^{37}$ The regulatory mechanism of the nursing profession in South Africa is through a register. As the locus of control of any profession, the register does not only give identity to the body of persons who possess specialised knowledge, skills, standards and ethical integrity, but it also allows for control over such persons whose names are subject to public scrutiny. 38

\section{The influence of the law on professional practice}

Laws generally, and relevant legislation in particular, are endorsed to regulate and control the practice of health professionals. Such laws form the protective framework for the health, safety and welfare of the citizens of a country so that they are protected against unauthorised, unqualified

36 See Searle, Human \& Mogotlane Professional Practice: A Southern African Nursing Perspective 5th ed (2009) 49.

37 Ibid.

38 See Armstrong, Bhengu, Kotze, Nkonzo-Mthembu, Ricks, Stellenberg, Van Rooyen \& Vasuthevan A new approach to Professional Practice (2013) 73. 
and improper practice by the health professionals. This originates from the concept of justice for all, as it provides for the protection not only of the health users, but also for the health professional as it defines the parameters of their practice. ${ }^{39}$

Justice is a fundamental component for the attainment of social peace and human welfare. Legislative instruments influence social control for rules of action as they are binding and enforced on all citizens of the country. In a profession, the law identifies who shall serve in such a profession and enforces its member's acts and omissions. ${ }^{40}$ In such an environment, it is absolutely essential, that nurses understand the law affecting the nursing profession. They are therefore required to be trained and to have a thorough knowledge of the related Acts that impact on their practice in South Africa. ${ }^{41}$ The relevant and applicable legislation is dealt with in seriatim below.

\section{An examination of relevant and applicable legislation}

\section{The Constitution of the Republic of South Africa ${ }^{42}$}

Chapter 2 - the Bill of Rights of the Constitution articulates the principles that are fundamental to the ethics of nursing. The ethical principles of beneficence, non-maleficence, autonomy and justice are reflected in the Bill of Rights. This contains the detailed provisions concerning civil, political, economic and social rights. Ethical principles of beneficence align to the right to life (section 11), access to health care (section 27-(1)) and access to information (section 2-(1)). Non - maleficence is reflected in the Constitution as the 'right to an environment that is not harmful' (section 24-(a)), 'not to be treated in a cruel, inhumane or degrading manner' (section 12 -(1)) and 'not to be subjected to medical or scientific experiments without consent' (section 12-(2)(c)). A person's right to bodily and psychological integrity (section 12(2), dignity (section 10), privacy (section 14) and life (section 11) reflects autonomy. Justice and fairness echoes the right to equal treatment and non-discrimination (section 9) and the right to lawful, reasonable and procedurally fair administrative treatment (section 33)'. ${ }^{43}$ It follows that these rights and ethical principles must be observed and respected for the purpose of health care in a medical setting. The Constitution and the rights entrenched therein serve as the backdrop for the ethical and legal practice for nurses, patients and for SANC. ${ }^{44}$

\section{Searle, Human \& Mogotlane supra n36 at 149.}

40 Ibid.

41 See Mellish, Oosthuizen \& Paton An Introduction to the Ethos of Nursing 3rd ed (2010) 3.

42 The Constitution refers to the Constitution of the Republic of South Africa, unless otherwise stated.

43 Mathibe-Neke The role of the South African Nursing Council in promoting ethical practice in the nursing profession: a normative analysis (MSc (Med) dissertation 2015 University of Witwatersrand) 23-24.

44 Reference here is made to Chapter 2 of the Constitution of Republic of South Africa. 


\section{The National Health Act, 2003 (Act 61 of 2003)}

Prior to the implementation of the National Health Act 61 of 2003 (hereinafter referred to as the National Health Act), the National Patients' Rights Charter was formulated by the Department of Health and launched in 1999 to serve as a guideline to people seeking health services, as well as to health institutions concerning the rights and duties of people in the health sector. The guidelines in the National Patients' Rights Charter are similar to those mentioned in the National Health Act and the Health Professions Council of South Africa's (HPCSA) guidelines and also have as part of its mission, the realisation and protection of the patients' rights to access to health care as well as to privacy and a healthy and safe environment. ${ }^{45}$ It, therefore, follows that the National Health Act combines the country's health system in a common goal to promote and improve health care delivery within the aforementioned guidelines. The Act promulgates the obligations imposed by the Constitution and other relevant health legislation including nursing care, rights of the health users and the responsibilities of the healthcare provider. ${ }^{46}$

\section{The Nursing Act, 2005 (Act 33 of 2005)}

Nurses have a duty to be trained and to formulate an understanding of the elements of the law relating to their practice, training and other issues of the nursing profession. Chapter 2 of the Nursing Act articulates the regulation and practice requirements for the nurse. ${ }^{47}$ The Nursing Act enables the nurse to recognise the professional council duties and the relevant sections that detail the regulations or rules that guide and regulate the profession. ${ }^{48}$ Sections 1 to 4 of Chapter 1 is explicit in detailing SANC's roles, responsibilities and objectives of the profession. ${ }^{49}$

The Nursing Act is the binding force to provide recognition and cohesion to the nursing profession and has been promulgated so that it is in the interest of the public. The fundamental purpose of the Act is to ensure regulation by statute by implementing a sound and effective level of nursing service to all citizens. The Nursing Act provides for the existence of SANC, which as has been described above, is responsible for the regulatory processes applied in nursing in South Africa. 50

45 Mellish, Oosthuizen \& Paton supra n41 at 169.

46 The relevant and applicable sections in this regard are Chapter 1 and Chapter 2 of the National Health Act 61 of 2003.

47 See Chapter 2 of the Nursing Act 33 of 2005.

48 Searle, Human \& Mogotlane supra n36 at 155.

49 See Chapter 1 of the Nursing Act 33 of 2005.

50 Searle, Human \& Mogotlane supra n36 at 155. 


\section{Other regulatory structures}

\section{The South African Nursing Council (SANC)}

South Africa attained a significant milestone by being amongst the forerunners in the world to achieve State registration for nurses with the establishment of SANC in 1944. SANC is a statutory body established and legally recognised by Parliament. It exists as a legal entity in its own right with powers and the authority to independently control the activities and other issues related to the profession. ${ }^{51}$ The core purpose of SANC relates to public protection through maintaining professional standards and conduct, and improving knowledge and skills of the nurse practitioners. This assents with the state's main responsibility to the public of safe and quality health care. ${ }^{52}$ There is a close collaboration between government and SANC as the Nursing Act assigns powers to SANC. Although SANC has the independence to regulate the profession, it is accountable to government in terms of its activities and the profession. Amongst a host of functions, an important function of SANC is the regulation and control of professional conduct. The Nursing Act, as referred to above, provides for disciplinary control of the profession by SANC. This strives to ensure that the ethical practice of nursing is primarily intended to protect the public. It attempts to protect the nursing practitioner and the interests of the public so that the trust between the public and the profession is maintained. ${ }^{53}$

In cases of misconduct, SANC is given quasi-judicial powers to enquire into charges of misconduct and to impose sanctions, or penalties where misconduct is evident. The procedure for misconduct and the penalties are prescribed by law, as the outcome may have severe social and economic consequences. ${ }^{54}$ The advocacy role of SANC should be aimed at enhancing professionalism in the nursing profession which entails a commitment to society that demonstrates a nursing practitioner's scientific knowledge, accountability and responsibility. 55 McCleod Sordjan postulates that although SANC's vision is clear in articulating the standards of professional practice, there is a need for development in areas where legal accountability and liability need emphasis. It is provided that precise guidelines on legal aspects will only serve to further enhance the nursing knowledge base in the interest of all stakeholders. ${ }^{56}$

\footnotetext{
51 Ibid.

52 Ibid.

53 See Armstrong, Bhengu, Kotze, Nkonzo-Mthembu, Ricks, Stellenberg, Van Rooyen \& Vasuthevan A new approach to Professional Practice (2013) 74.

54 Searle, Human \& Mogotlane supra n36 at 156.

55 McLeod-Sordjan 'Evaluating Moral Reasoning in Nursing Education' (2014) 21(4) IJHCP 474-480.

56 Ibid.
} 


\section{Regulations Relating to the Scope of the Practice (hereafter the Scope Regulations)}

The scope of practice of a nurse entails the acts and procedures which may be performed by the scientifically based physical, chemical, psychological, social, educational and technological means applicable to health care practice'. ${ }^{57}$ An important regulatory function is to determine the scope in which a practitioner may function. In the Nursing Act, the scope of practice is outlined in section 30 and details are provided in the regulations and rules according to section 58 and 59. Therefore the Regulations provide for the legal scope of practice for professional nurses and all practitioners are legally obliged to comply with these prescriptions. ${ }^{58}$ It is vitally important that a practising nurse know their scope of practice as well as the scope of other categories in the profession. The Regulations on the scope of practice for nurses define the scope of practice of registered persons, the conditions under which registered persons may carry out their professional obligations, the control which will be exercised by SANC over the practice of registered persons and the inspections which will be carried out regarding nursing education institutions. ${ }^{59}$

Although the scope of practice is composed as a flexible framework in order to make provision for different areas of practice and allow new developments in health and nursing care, a limitation to the Regulations is that it does not specify the skills and methods which the nurse should use when caring for a patient. Researchers have argued in favour of this limitation as there cannot be a list of tasks because it negates the true nature of nursing which is more than tasks and procedures. However, the broad guidelines that allow for the expansion and development of the nurse's role in order to keep pace with technology and advances in the health and nursing industry have also led to nurses uncertainty in the limitations and boundaries of their scope leading to them practicing care without acquiring full competency. 60

With regard to a study undertaken by Lubbe in South Africa to determine the nurse's scope of practice and the implication for quality nursing care, it was found that there were an alarming number of risk assessments performed by nurses not licenced or enrolled to perform the assigned tasks. This highlighted implications for quality nursing care and potential risk for the patient and the institution. The author surmised the need for emphasis of nurses performing tasks within their scope of practice for which they are licenced or enrolled. Nurses that lack the

57 The South African Nursing Council Government Notice Regulation No.2598 (R2598) of 1985 as amended.

58 Geyer 'Scope of Practice' (2009) 20(1) Professional Nursing Today 4-5.

59 Searle, Human \& Mogotlane supra n36 at 177.

60 Geyer supra n58. 
required competency are not adequately prepared to perform tasks unsupervised even in the current global nursing shortage crisis. ${ }^{61}$

The findings in this study validate a review of a more defined scope of practice that provides a more detailed outline of the permissible interventions and procedures for the various categories of nurses. This will obviate nurses acting outside their prescribed domains of practice and rendering safe, competent care that meets the ethical and legal realms of the profession. Therefore, the researcher emphasises the need for nurses to be knowledgeable of their legal obligations in order to empower their decision making when commissioned to render care. A thorough understanding of their legal responsibilities will guide their actions and protect the patient and the nursing professional. The strategies discussed hereunder are proposed in response to the gaps that have been identified and the problems experienced in the nursing profession.

\section{Strategies for providing quality health care}

In a South African study conducted by Dorse, nurses from selected private hospitals were evaluated on their knowledge regarding legal aspects in their practice. Although the findings from the study indicate that the majority of the nurses are knowledgeable about their legal responsibilities and the legislation governing their practice, the results also revealed that there are a significant number of nurses who lack important knowledge on some aspects. These aspects include: nurses operating outside of their scope of practice, that they do not operate within the legal guidelines of the profession, and do not understand their scope of practice. Nurses do not always adhere to the patient's rights. They function in an unsafe working environment and do not feel skilled or sufficiently competent to perform their duties. Nurses do not address patient safety in all aspects of care. They do not inform families of potential risks that might arise, and it has been observed that lower categories of staff do not operate under direct supervision. ${ }^{62}$

What is evident is that there is a crucial need for nurses to be kept abreast of their legal liability and current trends and legal developments that apply in their day-to-day care. It has been established that sufficient information is disseminated during the training of nurses for the various categories. However, what has emerged is that nurses find the application of this knowledge challenging. Nursing is a service-oriented profession and it must advance and keep pace with the advancing technology, newer problems, and growing demands of consumers. The following strategies have been identified to ensure that there is

61 Lubbe 'Nurses' Scope of Practice and the Implication for Quality Nursing Care' (2013) Journal of Nursing Scholarship 58-64.

62 Dorse Legal and Ethical aspects of nursing practice in selected private hospitals in the Western Cape Metropolitan area (MCur dissertation 2008 University of Stellenbosch) 38. 
continuous and intensified efforts by nurses to provide quality health care services: -

\section{The inclusion of a module on medical law and practice in the nursing curriculum}

Nurses have an obligation to act within their scope of practice, competence and legal boundaries. Their foremost responsibility is to safeguard the patient and family against harm, abuse, neglect and deprivation. It is therefore submitted that knowledge on medico-legal responsibilities will better prepare student nurses and encourage accountability for their actions. As discussed, the legal framework for nurses is vast and overlaps with other significant legislation that impact their practice. Thus, it is submitted that a module of this nature will also empower the nurse to appraise the laws governing their practice and impose an appreciation of ethical and legal issues. It is proposed that this will equip the nurse with applicable knowledge and an understanding of aspects relevant to their daily practice. Especially for the registered nurse practitioner who has a wider scope of practice compared to other categories, this should be considered as a mandatory module as its significance will be valuable in practice as it is the Registered Nurse whose function encompasses decision making, supervision, delegation and management of patient care. Aspects of medical law may include subject matter such as medical law and practice, forensic nursing, human rights, and HIV and the law. The aim of equipping nurse practitioners with knowledge on legal aspects relevant in the current and dynamic healthcare environment may be achieved if the relevant knowledge is disseminated in the appropriate context.

\section{To facilitate and support interdisciplinary education}

In order to translate a succinct approach to education and training on medical law and its relevant matters to enhance safe nursing practice, it is necessary that opportunities be created for in-service training, lectures, seminars, continuous professional development modules and workshops by medico-legal experts and medical expert witnesses. To corroborate the findings of the studies by Osingada et al, Mali and Mali and Sharmil as discussed above, it was revealed that there is a marked deficiency in legal knowledge amongst the nurses. The education and training that is suggested will enable nurses to update and keep abreast of legislation in the current health care context. The transference of experience, knowledge and information will prove to be educational for the nurse practitioner as the realities of the nature of the incidents and cases will enable a beneficial encounter for the nurse.

\section{A need for reflection on medico-legal incidents that occur at institutions}

A common response after an unfavourable incident is to attempt to conceal and avoid the details of the matter in fear of negative publicity or 
the possibility of a defamation suit to those involved. Reflection of the events and debriefing will provide a safe evaluation of one's practice. It allows one to revisit the event, thus enabling identification of strengths, weaknesses and potential opportunities for improvement should a similar incident recur. The nurses must be debriefed using the ethical and legal framework to reinforce the nurse's actions and decisions in context. Real incidents with medico-legal implications may be used for reflection exercises within larger groups as well to introspect on one's own practice.

\section{To enable the availability of resources such as legal nurse consultants or legal advisors at institutions}

When decision making is challenging and ethical issues arise, knowledge and expertise may be critical for both the patient and the nurse. Often, the nurse is faced with situations where the struggle between ethical and legal obligations arise. There may be uncertainty and indecisiveness due to a lack of knowledge on matters pertaining to their actions. Although decision making and problem-solving regarding legal matters may improve with experience and rank, there may be some legal issues that remain unclear and obscure to an inexperienced individual. The researcher submits that making such resources available will be of immense value and may potentially even obviate a medico-legal incident. Whilst there is no education and training currently available in South Africa for legal nurse consultants, it is proposed that more experienced nursing professionals may be identified and trained as expert witnesses, advisors and consultants who may, therefore, be utilized as a valuable resource in this regard.

\section{To establish a medico-legal forum for nurses}

A forum of this nature comprising nurses as well as legal experts can be established to meet (on a suggested quarterly basis), to conduct a mortality review of all patients within a specified period to identify and discuss legal and ethical issues related thereto. An analysis of patient cases in such a forum may also emphasise the nurse's shortcomings in the delivery of care and foster a more conscientised approach. A comprehensive, purposive and systematic review of these cases can aid in identifying the causes of the nursing malpractice, morbidity or mortality associated with these cases. One will need to define and analyse the nursing care related injuries and insults and explore and develop preventative measures and strategies for safer practice. It is submitted that the sentiment that "when human error is systematically studied, valuable lessons can be learned and safety is improved, 63 certainly rings true with the practice.

63 See Beckmann Nursing Negligence: Analyzing Malpractice in the Hospital Setting (1996) 1-2. 


\section{Concluding remarks}

The healthcare institution is one of the most dynamic and complex organisations in society. It encompasses a multitude of functions, with nursing care constituting the single largest component of the healthcare industry. ${ }^{64}$ The nursing function is the mainstay of the organisation in fulfilling its objectives in relation to patient care. The primary purpose of the nursing function is to provide safe, individualised, comprehensive and effective care to patients through the execution of the nursing process. Nurses play an integral role in providing society with widespread and all-inclusive healthcare. The knowledge that is garnered through education and clinical practice forms the basis of safe and effective nursing care. The nurse practitioner is the only member of the health care team responsible for the hospitalised patient over a 24 hour day. His or her interventions are guided by policies and procedures established by the country, the profession, and the healthcare institution in accordance with accepted standards of care. ${ }^{65}$

The research undertaken has revealed that relevant legal knowledge and an understanding and application of the law is a key element for a safe and competent professional practice. The strategies that have been highlighted above are submitted to enhance a nurse's understanding of laws governing the nursing practice and are to be implemented to address the gaps that have been identified. In light of this submission, the following quotation by Ashton cited by Oyetunde and Ofi, is most appropriate - 'if more nurses are knowledgeable about the laws of the land and that which governs their practice, there will be little or no problems in nursing practice since laws guide human conduct. ${ }^{, 66}$

\footnotetext{
64 Ibid.

65 Ibid.

66 Oyetunde \& Ofi 'Nurse's knowledge of legal aspects of nursing practice in Ibadan, Nigeria' (2012) 3(9) JNEP 80.
} 